\title{
Activization of Development of Economically Peripheral Regions of Russia
}

\author{
Yury Nurmagomedovich Sagidov \\ Federal State Budgetary Institution of Science Institute of Social and Economic Researches of the Dagestan Scientific Center of the Russian \\ Academy of Sciences, Makhachkala, Russian Federation
}

Email address:

sagidov_2014@mail.ru

\section{To cite this article:}

Yury Nurmagomedovich Sagidov. Activization of Development of Economically Peripheral Regions of Russia. International Journal of Energy and Environmental Science. Vol. 4, No. 6, 2019, pp. 77-85. doi: 10.11648/j.ijees.20190406.12

Received: April 9, 2019; Accepted: May 23, 2019; Published: December 25, 2019

\begin{abstract}
In article the problem of overcoming a peripheral state and activization of development of economy underdeveloped the agrarnooriyentirovannykh of regions of Russia as one of the directions of ensuring the balanced territorial development of the country and realization of integration effect of synergy and also weakening of the contradictions and threats connected with big differences of social and economic levels of regions is considered. The author of article sets tasks: definition of type of the problematical character inherent in underdeveloped regions of the certain country in a mirror of the known Theory of peripheral economy of the countries of the world; identification of the lag reasons, characteristic of type of problematical character, in development; search and justification of the directions and measures of achievement of the selfmovement of regions in development; definition of a role of the state and civil institutes in a solution of the problem of activization of development of underdeveloped regions. A basis of a research are fundamental works of domestic and foreign scientists in the field of regional studies and problems of development of the backward countries of the world. During the research the cross-disciplinary and statistical types of the analysis allowing to develop conceptual approaches to development of backward regions are used. As a result of a research the factors influencing reproduction of a chronic condition of backwardness of underdeveloped regions, existence of the altruistic and egoistical beginnings in qualities of a condition of the public environment are defined. An assessment of a role of public administration and civil activity in activization of development of regions with economy of peripheral character is given. The thesis about refusal of dogma of the developed interregional division of labor is proved, the regions of agrarian specialization deprived of a minimum of the industrial enterprises are doomed to loss of a commercial crop, modernization lag and preservation of economic vegetation. A key link of the institutional transformations directed to activization of development of the country and its regions, the author considers need of regeneration of the existing public administration. Achievement of responsibility of subjects of management of all levels for effectiveness of social and economic development has to be a purpose at the same time. Scientific developments and the offered approach to overcoming the contradictions connected with uneven development of regions of the country can be used when developing measures of the institutional transformations directed to activization of development of regions with economy of peripheral character.
\end{abstract}

Keywords: Unevenness of Development of Territories of the Country, Economy of Peripheral Character, Factors of Counteraction to Development, Socially Wednesday, Public Administration, Activity of the Population

\section{Introduction}

The imperative of rapprochement of economic levels of regions as conditions of the balanced territorial development of economy of the country, is present at all normative legal acts concerning the strategy of planning, national security and the state national policy of Russian Federatsiil. Realization of this installation assumes a catalyzing of economic effectiveness on the basis of unifying effect of synergy. However unifying integration processes can generate not only positive effectiveness, but also negative [1]. What will be an effectiveness depends on differences in 
economic development of regions, their scientific and technical culture and the developing civilization qualities of the public environment. Russia is the center of regions with big asymmetry in levels of economic development, differences in mentality of the population, level and specifics of culture to the system of values and the imperious relations. Weak accounting of these factors can have the braking impact on development of the country.

That part of regions of the country which is in a condition of chronic lag in many respects has an impact on a trend of increase in differences in economic and social development. Researches of intrinsic bases and reasons of lag of regions of this group and definition of approaches to acceleration of their development is one of problems on which solution the economic success and prevention of accumulation of contradictions and potential of threat of its territorial integrity in many respects depends $[2 ; 3]$. In article the attempt of search of a solution of the problem of acceleration of development of regionovoutsiders of the certain country in a mirror of the Theory of peripheral economy becomes ("Etc. э.").

\section{Depressiveness and Periferiynost as Various Types of Problematical Character}

In characteristic of the economic development of Russia proceeding to the current of last quarter of this century the picture in which four large-scale crises are reflected prevails: "transformational" - 1890-1992, "debt" - 1998-2000, as a result of world financial crisis - 2008-2009 and flowing since 2013 - "economical and political" [4]. It is represented that such characteristic does not correspond to classical understanding of essence of crisis. Reaching higher level of development of a system (the country, the region, the industry, the enterprise, etc.) has to be result of overcoming crisis. Russia during all quarter of the century had a vector of development of negative orientation. The series of processes of recession (in the periods stated above) and stagnation proceeded (in intervals of the periods of recession), but economic development was not. The economic growth taking place in zero years was caused not by modernization development, but speculative factors, connected with the fact that Russia was focused on dredging from storerooms of the earth of the resources formed there not by the activity of people which is a source of wealth and success of economy according to A. Smith [5], but creation of the nature. That is the negative vector of development determines type of crisis in Russia only by one characteristic - "transformational". At the same time, as follows from performances of the academician S. Glazyev, Russia not only did not follow a way of development of the 6th technological way (nanotechnologies, engineering biology), but also considerably lost positions of the 5th way (microeconomics, the software) formed in the late eighties years of the last century [6].

The maximum assessment exceeds minimum by 5.2 times.
Rather dynamically those regions which as N. Zubarevich notes, appeared in more favorable conditions for concentration of the capital develop. So, according to the RIA Rating Agency the maximum integrated indicator of ratings of social and economic levels of territorial subjects of the Russian Federation in 2017 made the size of 71.2 points (Moscow) and minimum - 13.8 (Jewish autonomous area). The difference between the maximum and minimum estimates makes 5.8 multiple size [8]. If to look in temporary aspect, then process of increase of asymmetry in the levels of development is noticeable. In the provided drawing the schedule of ranging of territorial subjects of the Russian Federation in size VRP per capita in 2016 is presented. The same ranging was carried out by workers of SOPS following the results of 2000 [9]. Ranging practically does not change except for separate movements within five near ranks. The distinction is that at most on ordinate axis in 2000 (730\%) there is more minimum $(22.8 \%)$ by 32 time, and at most $2016(980 \%)$ there is more minimum $(22.0 \%)$ by 45 times. That is the asymmetry increases in the level of development of territories of Russia.

Thus, the imperatives of rapprochement of economic levels of regions reflected in regulations remained formal spells, but not reality. It is difficult not to agree with the academician A. Tatarkin who considers that the gap increasing every year in development of Russian regions interferes with carrying out uniform economic policy of system and sustainable development of all subjects of national market economy, civilized arrangement of all Russian space [10].

Regions of the country are divided by the Russian Government Analytical Centre into four groups: advanced, developed, moderately developed and less developed (Table. 1) [11]. The first three groups are subdivided into subgroups of regions with the economic specialization which is mainly aimed at the industrial development. Our attention is focused on seven regions of subgroup "less developed agrarian" - the Republic of Adygea, the Republic of Dagestan, the Republic of Ingushetia, Kabardino-Balkar Republic, the Cara-chayevoCircassian Republic, the Chechen Republic and the Republic of Kalmykia. The choice of these territorial subjects of the federation as objects of a research is caused by their geographical adjacency and historically developed community of many lines of practical culture and mentality.

At a formulation "less developed agrarian" there is a sparing semantics: "the "backward regions outsiders" which were less developed", but not. The condition of these regions is usually formulated as "the problem region" or "the depressive region". The first formulation does not concretize a problematical character essence. As for a formulation "the depressive region", it is doubtful concerning characteristic of a condition of regions outsiders as because of backwardness of the industry influence of waves of crisis splashes almost does not influence these regions. 


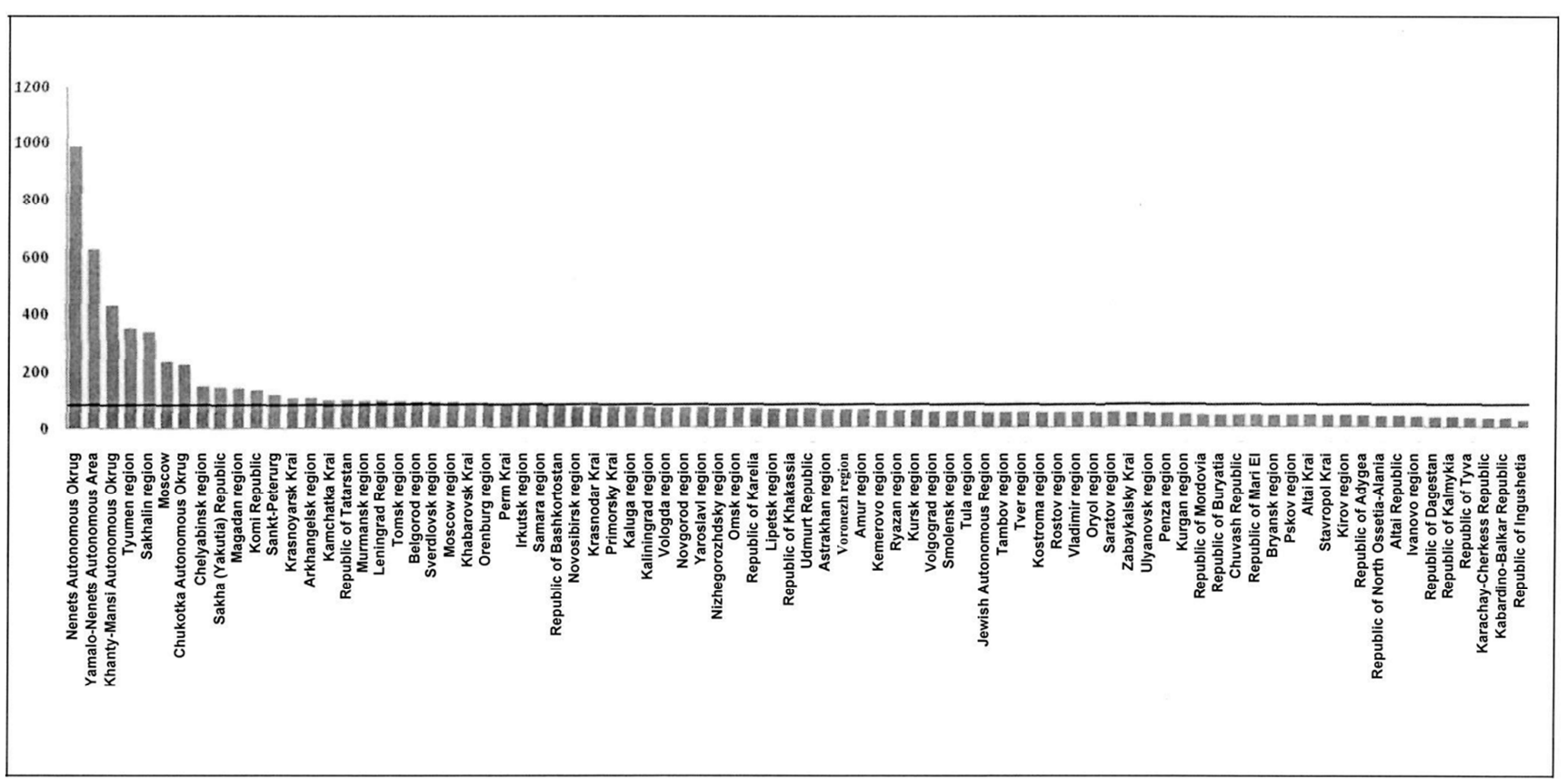

Figure 1. Runding of territorial subjects of the Russian Federation in the VRP per capita in 2016 (in relation to the average Russian level, in \%). It is executed by the author by data Rosstat: Regions of Russia. Socio-economic indexes - 2014.

Table 1. Classification of regions of Russia by the level of development/.

\begin{tabular}{|c|c|c|}
\hline \multirow[t]{2}{*}{ Advanced } & $\begin{array}{l}\text { Financial and economic } \\
\text { centers }\end{array}$ & $\begin{array}{l}\text { Moscow Region. Moscow. } \\
\text { St. Petersburg }\end{array}$ \\
\hline & Raw export-oriented & Komi Republic Tyumen region (including KhMAO, YaNAO) \\
\hline \multirow{3}{*}{ Developed } & With diversified economy & $\begin{array}{l}\text { Rostov Region. Tatarstan Nizhny Novgorod Region. Samara Region. Sverdlovsk Region. Novosibirsk } \\
\text { Region. Sakha (Yakutia) Sakhalin Region }\end{array}$ \\
\hline & $\begin{array}{l}\text { With a support on } \\
\text { manufacturing industry }\end{array}$ & $\begin{array}{l}\text { Lipetsk Region. Yaroslavl Region. Vologda Region. Leningrad Region. Novgorod Region. Chelyabinsk } \\
\text { Region. Irkutsk Region. } \\
\text { Omsk Region }\end{array}$ \\
\hline & $\begin{array}{l}\text { With a support on mining } \\
\text { industry }\end{array}$ & $\begin{array}{l}\text { Belgorod Region. Murmansk Region. Bashkortostan Perm Krai } \\
\text { Krasnoyarsk Krai Kemerovo Region. Tomsk Region } \\
\text { Vladimir Region. Ivanovo Region. Kaluga Region. Kostroma Region. Ryazan Region. Smolensk Region. }\end{array}$ \\
\hline \multirow{2}{*}{$\begin{array}{l}\text { Moderately } \\
\text { developed }\end{array}$} & Industrial and agrarian & $\begin{array}{l}\text { Tver region. Tula Region. Karelia Arkhangelsk Region (including Nenets Autonomous Okrug) Kaliningrad } \\
\text { Region. Udmurtia Khakassia Primorsky Krai Khabarovsk Krai }\end{array}$ \\
\hline & Agrarian and industrial & $\begin{array}{l}\text { Krasnodar Krai. Astrakhan Region. Volgograd Region. North Ossetia. Stavropoklksky region. Mari El } \\
\text { Mardovia Chuvashia Kirov Region. Orenburg Region. Penza Region. }\end{array}$ \\
\hline $\begin{array}{l}\text { Less } \\
\text { developed }\end{array}$ & $\begin{array}{l}\text { Less developed raw } \\
\text { Less developed agrarian }\end{array}$ & $\begin{array}{l}\text { Zabaykalsky Krai Amur Region. Magadan Region. Chukotka Autonomous Okrug } \\
\text { Adygea. Kalmykia. Dagestan. Ingushetia. Kabardino-Balkaria. } \\
\text { Karachay-Cherkessia. Chechnya. Altai Tyva. Jewish Autonomous Region. }\end{array}$ \\
\hline
\end{tabular}

It is made according to the Report in Analytical center at the Russian Federation "Types of Russian regions: stability and shifts in 2003-2013" / Authors: Golyashev A. V., Grigoriev L. M. [11]

The term "depression" in relation to reflection of an economic condition of any system (the country, the region, the industry, the enterprise and so forth) has classically defined characteristic of crisis. Mainly industrially developed systems with an essential economic potential are subject to crisis. The main manifestations of crisis are: production falling, peak rise in unemployment, decline in income of the enterprises and population. Duration of a depression is limited in time, as a rule, to the period up to 4 years [12]. The depression is overcome by measures of organizational, financial and technological improvement. An exit from a condition of a depression to rise, as a rule, gives a system on higher level of development and growth of economy.

However, passed not 4 years as Russia, having entered since the beginning of 90 years a condition of crisis, did not follow a way of modernization development. Therefore the classification of regions of Russia by levels of their development and economic specialization presented by the Russian Government Analytical Centre, reflects not a depression, but already new established state of the economy of the country with the arising signs of a periferiynost structural orientation to sale of natural resources and attenuation industrial потенциала*.

Provisions of the Theory of peripheral economy among 
which adherents economists R. Prebish (the initiator of the theory), S. Amin, F. Cardozo, Dus Santos, I. Vallerstayn, S. Artobolevsky, S. Furtado, etc. are noticeable [13 - 19], etc. The countries of the world are subdivided into the center, the periphery, the semi-periphery and the periphery. The center is the developed countries of the world which are a part of the countries of the Organization for Economic Cooperation and Development - OECD. Other countries are considered as economically peripheral as indicators of level of their development in size are removed from indicators of the developed countries.

If to correlate provisions of the specified Theory on the certain country - Russia, then its regions can be subdivided into categories too: developed, on-luperiferiynye and peripheral. At such division "less developed agrarian" regions of Russia get under definition not of regions with depressive economy, and regions with peripheral economy.

Business is not simple in distinction of verbal expressions "depressiveness" and "periferiynost". These are categories, different in essence. The Periferiynost - a problem more difficult, than depressiveness. Its reasons are not only in the economy plane; they include "non-economic sides of economy" [20]. The difference in approaches to ensuring success of development in one and other cases depends on understanding of difference in depressiveness and a periferiynost respectively.

R. Prebish formulates the factors defining an essence of a peripheral state: "The specifics of the periphery are shown in everything: in the sphere of the equipment and consumption, in production structure, in the levels of development and democratization, in the system of land use and formation of surplus, in demographic growth" [13]. This comprehensive reflection of an essence of peripheral economy. Using these Table 2, we will consider in relation to seven explored regions a circle of indicators still limited by positions of characteristic of a depression of a system.

Table 2. Socio-economic indexes of the explored territorial subjects of the federation, 2013.

\begin{tabular}{|c|c|c|c|c|c|c|c|c|c|}
\hline $\begin{array}{l}\text { № } \\
\text { II/II }\end{array}$ & & $\begin{array}{l}\text { Russian } \\
\text { Federation }\end{array}$ & $\begin{array}{l}\text { Republic of } \\
\text { Adygea }\end{array}$ & $\begin{array}{l}\text { Republic of } \\
\text { Kalmykia }\end{array}$ & $\begin{array}{l}\text { Republic of } \\
\text { Dagestan }\end{array}$ & $\begin{array}{l}\text { Republic of } \\
\text { Ingushetia }\end{array}$ & $\begin{array}{l}\text { Kabardino- } \\
\text { Balkar } \\
\text { Republic }\end{array}$ & $\begin{array}{l}\text { Karachay- } \\
\text { Cherkess } \\
\text { Republic }\end{array}$ & $\begin{array}{l}\text { Chechen } \\
\text { Republic }\end{array}$ \\
\hline 1. & $\begin{array}{l}\text { The cost of fixed assets on soul of the } \\
\text { population, thousand rubles } \\
\text { Frequency rate of distinctions }{ }^{3}\end{array}$ & $\begin{array}{l}929,4 \\
1\end{array}$ & $\begin{array}{l}356,9 \\
-2,6\end{array}$ & $\begin{array}{l}441,0 \\
-2,1\end{array}$ & $\begin{array}{l}332,6 \\
-2,8\end{array}$ & $\begin{array}{l}145,1 \\
-6,4\end{array}$ & $\begin{array}{l}252,9 \\
-3,7\end{array}$ & $\begin{array}{l}337,2 \\
-2,8\end{array}$ & $\begin{array}{l}300,4 \\
-3,1\end{array}$ \\
\hline 2. & $\begin{array}{l}\text { The cost of fixed assets in the industry, } \\
\text { thousand rubles } \\
\text { Frequency rate of distinctions }\end{array}$ & $\begin{array}{l}251,8 \\
1\end{array}$ & $\begin{array}{l}71,7 \\
-3,5\end{array}$ & $\begin{array}{l}34,6 \\
-7,3\end{array}$ & $\begin{array}{l}43,4 \\
-5,8\end{array}$ & $\begin{array}{l}16,2 \\
-15,5\end{array}$ & $\begin{array}{l}49,0 \\
-5,1\end{array}$ & $\begin{array}{l}62,4 \\
-4,0\end{array}$ & $\begin{array}{l}53,2 \\
-4,7\end{array}$ \\
\hline 3. & $\begin{array}{l}\text { The cost of fixed assets per capita in } \\
\text { agriculture } \\
\text { Frequency rate of distinctions }{ }^{3}\end{array}$ & $\begin{array}{l}25,6 \\
1\end{array}$ & $\begin{array}{l}27,4 \\
0,9\end{array}$ & $\begin{array}{l}39,2 \\
0,7\end{array}$ & $\begin{array}{l}23,0 \\
-1,1\end{array}$ & $\begin{array}{l}10,8 \\
-2,4\end{array}$ & $\begin{array}{l}27,8 \\
0,9\end{array}$ & $\begin{array}{l}57,2 \\
0,4\end{array}$ & $\begin{array}{l}9,2 \\
-2,8\end{array}$ \\
\hline 4. & Specific weight of urban population, in \% & $\begin{array}{l}74,2 \\
25,8\end{array}$ & $\begin{array}{l}47,0 \\
53,0\end{array}$ & $\begin{array}{l}45,1 \\
54,9\end{array}$ & $\begin{array}{l}40,4 \\
59,6\end{array}$ & $\begin{array}{l}42,4 \\
57,6\end{array}$ & $\begin{array}{l}52,3 \\
47,7\end{array}$ & $\begin{array}{l}42,7 \\
57,3\end{array}$ & $\begin{array}{l}34,8 \\
65,2\end{array}$ \\
\hline 5. & $\begin{array}{l}\text { Investments into fixed capital per capita, } \\
\text { thousand rubles } \\
\text { Frequency rate of distinctions }\end{array}$ & $\begin{array}{l}92,4 \\
1\end{array}$ & $\begin{array}{l}35,8 \\
-2,6\end{array}$ & $\begin{array}{l}51,8 \\
-1,8\end{array}$ & $\begin{array}{l}60,3 \\
-1,5\end{array}$ & $\begin{array}{l}29,4 \\
-3,1\end{array}$ & $\begin{array}{l}25,7 \\
-3,6\end{array}$ & $\begin{array}{l}39,9 \\
-2,3\end{array}$ & $\begin{array}{l}30,8 \\
-3,0\end{array}$ \\
\hline 6. & $\begin{array}{l}\text { Gross regional product per capita, one thousand } \\
\text { rubles } \\
\text { Frequency rate of distinctions }\end{array}$ & $\begin{array}{l}376,4 \\
1\end{array}$ & $\begin{array}{l}161,7 \\
-2,3\end{array}$ & $\begin{array}{l}145,3 \\
-2,6\end{array}$ & $\begin{array}{l}145,4 \\
-2,6\end{array}$ & $\begin{array}{l}100,9 \\
-3,7\end{array}$ & $\begin{array}{l}131,9 \\
-2,9\end{array}$ & $\begin{array}{l}133,2 \\
-2,8\end{array}$ & $\begin{array}{l}88,5 \\
-4,3\end{array}$ \\
\hline 7. & $\begin{array}{l}\text { The number of able-bodied population } \\
\text { unoccupied in economy, } \% \text { of an able-bodied } \\
\text { part of the population }\end{array}$ & 10,1 & 28,0 & 14,3 & 24,6 & 63,8 & 27,4 & 23,7 & 47,2 \\
\hline 8. & $\begin{array}{l}\text { Population with monetary income below living } \\
\text { level, in } \% \text { of the total number of the } \\
\text { population }\end{array}$ & 10,8 & 12 & 35,4 & 10,1 & 19,5 & 18,6 & 19,5 & 19,7 \\
\hline 9. & $\begin{array}{l}\text { The total living space falling on one inhabitant, } \\
\text { sq.m }\end{array}$ & 23,4 & 24,4 & 22,8 & 17,1 & 13,5 & 18,7 & 20,1 & 18,1 \\
\hline 10. & Population on one hospital bed & 110,3 & 133,4 & 107,2 & 141,9 & 215,9 & 105,9 & 127,3 & 138,4 \\
\hline 11. & $\begin{array}{l}\text { The number of doctors is at } 1000 \text { people of the } \\
\text { population }\end{array}$ & 49 & 39 & 54 & 39 & 38 & 45 & 38 & 27 \\
\hline 12. & $\begin{array}{l}\text { Coefficient of natural increase of the } \\
\text { population }\end{array}$ & 0,2 & $-0,6$ & 4,7 & 13,3 & 17,7 & 6,6 & 4,4 & 19,9 \\
\hline 13. & $\begin{array}{l}\text { Coefficient of migration gain on } 10000 \\
\text { population }\end{array}$ & 21 & 50 & -122 & -73 & $63{ }^{5}$ & -32 & -17 & -35 \\
\hline 14. & $\begin{array}{l}\text { Specific weight of grants in income of the } \\
\text { consolidated budget, in } \%\end{array}$ & - & 64,6 & 90,7 & 94,8 & 99,0 & 83,8 & 77,9 & 92,0 \\
\hline
\end{tabular}

It is made by the author by data Rosstat [22]

Peripheral regions, unlike depressive, it is regions with a low economic potential and level of a commercial crop. Lag limits in technical equipment in general of all economy of regions and including the industries and also a ratio of specific weight of rural and urban population are reflected in the table by positions 1-4. In set they define agrarian orientation which is formalized in standard aktakh ${ }^{2}$.

Unlike peak Rostov unemployment during the periods of depressions, in peripheral regions is observed stable excess of unemployment rate in time and chronic part-time employment of the able-bodied population in economy (poses. 7). 
Difference of a periferiynost from depressiveness is also that economic lag is not limited in time, but a chronic brake for modernization development. The second Congress of Komintern, taken place in Moscow in 1920, the considered regions were given characteristic of their state as "The backward colonial outskirts of Russia" and carrying out measures for overcoming backwardness by industrialization was recommended [22]. Following recommendations, the development of regions which allowed to reach stratification of their level as agrarian-industrial was intensified and to pull together considerably with level development of other regions. Nevertheless, and in the Soviet period the social and economic level of regions remained below an average on Russia [23]. But also the reached positions were lost in the early nineties the last century, at the very beginning of the transformational period. Regions in one stage lost the most part of the large industrial enterprises (50\% self-destructed, the others were pressed down to 20 percentage powers), which were generators of a commercial crop. And also in one stage regions fell from agrarian-industrial level to level "less developed agrarian".

The chronic nature of lag in economic development of the explored regions predetermined their poverty. Despite the smoothing influence of federal grants (poses. 14), poverty of seven regions, as well as all in general subgroup regions "less developed agrarian" was and remains not the incidental phenomenon, and more expressed in comparison with other regions, defining places in the last ten among regions of Russia (poses. 8-11). One of the investigations is higher migration departure from regions in comparison with entrance (poses. 13).

\section{Weakness of Impulses of the Self-Movement in Development - The Main Reason of a Periferiynost, a Way of Overcoming}

Characteristic of a periferiynost of the region is not limited to reflection of its outsider situation on socio-economic indexes. The type of problematical character is defined also by the reasons generating it.

Almost all considered regions are in the last ten of 85 regions of the country on number of the dissolved marriage on 1000 people (The Republic of Dagestan - on the 83rd place, the Chechen Republic - on 84 and the Republic of Ingushetia - on 85). It says about high honoring of a role of family at which ensuring her economic welfare for the Caucasian and the Kalmyk is a criterion of the social importance: "it is not worse, than at others". That is the economic activity is predetermined immanently, and it is confirmed by effective self-expression. For example, at all times for the population of regions of the North Caucasus was and there is relevant an seasonal work. People left on the earnings necessary to marry the son, to build the house, to participate in weddings of acquaintances, etc. In the course of work in other regions Caucasians showed enviable creativeness. The same success and creativeness were shown and the Caucasians and Kalmyks working outside the regions and at constant bases show.

But the paradox is observed: at the qualities of high economic activity inherent in inhabitants of regions of the explored regions, the last quickly lost success achieved during the Soviet period and returned to a condition of chronic backwardness. The paradox is not inexplicable. First, economic success during the Soviet period was achieved as a result of the centralized public administration. The regional component of management had not sovereign auxiliary value. Secondly, Caucasians and Kalmyks are less successful in the regions that is connected with less favorable condition of the public environment in comparison with other regions [24].

The purposes of economic and social self-sufficiency can be reached by the person according to two beginnings of moral character:

- by the methods corresponding to the moral of universal values which fully corresponds to installations of all four religions professed in seven regions;

- in the ways of negative orientation (plunders, assignments, robbery).

Society as set of people as authors note, includes both beginnings [25]. The ability to self-development of society, its success depends on prevalence of this or that beginning. The prevalence will depend on a condition of the public environment - the developed practical culture, righteousness of the judicial system, objectivity of mass media, efficiency of the power - to what and to whom all of them serve - to society or its separate groups. Now on one of these points about the country in general, on and to its regions it is impossible to give a positive assessment.

The institutional installations entered in the country at the beginning of the 90th and the next years, seeded a virus of money-making and corruption, discrepancy between a measure of income and a measure of work and merits. That is it is about the created conditions of stimulation of qualities of the second beginning. These installations extend to all regions without exception. But in the developed regions of the country in which qualities industrial obshchestva7 are inherent though it is restrained, but the immunity of counteraction to a virus works. As for peripheral regions, its action is aggravated with existence of peripheral consciousness with elements as G. Myurdal claims, mentalities in practical perception of institutional installations [26]. Because of the taken roots paternalism counteraction of people to destructive institutional installations is weakened. It speaks simply: corruption, for example, is generation "from above", the investigation of the existing system of political arrangement. And time "from above", nothing to resist.

The Periferiynost of consciousness is shown also that the aspiration to consumer standards not adequate to their economic solvency is characteristic of wealthy members of society. As R. Prebish notes, meaning the countries of Latin America, the surplus of income is used not as means of investment of expansion of economy with adsorption of an 
unoccupied part of the population as it becomes in the developed countries, and on a necrosis in wasteful excesses. He writes: "I say at the top of the voice: the consumer society is incompatible with the purposes of eradication of society of underconsumption". [27, page 46]. It fully belongs also to the explored regions. A rich part of people of regions of the North Caucasus uses surplus, buying jewelry, to expensive car and branded tours, enter financial resources into coma, building houses palaces at the place of residence and duplicating acquisition of country houses on the coast, in forests and in other "cozier" regions of the country and even in the abroad.

To peripheral regions it is characteristic also:

1. more expressed, in comparison with industrial regions, authoritativeness of the power at the smaller initiative sovereignty;

2. lack of external control over the power from any body created by direct will of the people, but not the power;

3. backwardness of institutes of civil society, depression of civil activity.

These qualities are a basis of low efficiency of the regional power, the reason of an incubation of qualities of the second beginning, feebleness and complete dependence from the center. It is difficult to expect the sovereignty of an initiative of the regional power if the size of grants reads off scale 90 percent line of income of the consolidated budgets of regions (Table 2, poses. 14).

Follows from the stated material that chronic lag in economic development of regions - outsiders of Russia is a consequence of weakness of impulses of the self-movement in development. The last, in turn, is caused, first, the insufficient initiative sovereignty of a regional component of public administration of the country and, secondly, by existence of negatives of infernality in a condition of the public environment. According to the Theory of peripheral economy, all specified factors are the main signs and preservatives of peripheral economy [13] which can fully be correlated for characteristic of a periferiynost of economy of regions.

Speaking about weakness of impulses of the selfmovement in development of regions with peripheral economy, but not about self-development we reflect nuance of characteristic of a condition of a periferiynost and need of its overcoming. It does not contradict a concept about need of self-development of regions as the evolution including including, overcoming a periferiynost. The famous erudite economists of Russia were consolidated in unity of scientific vision of state of the economy of the country and the need of growth of economic independence connected with it and selfdevelopment of regions. Main argument: in Russia excessive centralization of powers of authority and financial means (up to $65 \%$ of all taxes and up to $90 \%$ of a natural rent) at the federal level at a simultaneous rigid regulation of initiative activity of regional and municipal authorities became the braking factors to sustainable development of the country and regions $[7 ; 10 ; 28]$. Having centralized powers of authority and resources, the state uses them extremely inefficiently.
There are not enough resources for ensuring full-blooded development of regions. At the same time bloodless regions cannot make a sufficient contribution to the centralized funds of the country. The vicious circle leading to consecutive increase of deficiency of development tools turns out.

Authors of the specified works made the recommendations of ensuring growth of independence and self-development of regions. Institutional transformations in the sphere of the financial relations - change of proportions in distribution between federal and regional budgets of tax revenues and a natural rent between federal and regional budgets are offered. It will allow regions to form a financial basis of economic independence.

Another, according to us, not less important direction of growth of economic independence and self-development of regions its improvement seems in measures for improvement of a condition of the public environment. Creation of conditions for disclosure of the energy of potential of constructive labor of economically active part of the population hidden in vain in all types of activity administrative, enterprise, performing has to be the purpose of these measures. Clubmen of the academician O. T. Bogomolov who includes a wide range of scientists and experts (economists, historians, philosophers, sociologists, jurists, political scientists, ecologists and practical workers) on the basis of cross-disciplinary approach revealed all defects of a condition of the public environment [20]. In many respects these defects appeared during the Post-Soviet period. One of the main reasons can call that in the Constitution of the Russian Federation the possibility of any state ideology is excluded. It is duplicated also in the Constitution of territorial subjects of the federation. The emptiness is occupied by various installations remote from the moral of the religion corresponding to universal values and precepts.

Long ago need to have the legitimate doctrine of purposes of distant development accepted by the vast majority of the population ripened. Vision of the acceptable future will create a prerequisite of distant motivation of orientation of people in the uniform course of creation. However the Soviet and foreign experience shows that the distant motivation will not be effective if in the current periods there is no constant confirmation of the movement on the way planned in the doctrine. From these positions it is necessary to prorevizirovat those institutional installations which work now. If there is same inefficient as a public administration today or the imperfection of justice at which, for example, for the stolen cow and the stolen 3 billion rubles identical punishments are defined will remain, then problematic there will be a formation on the way of creation. Compliance of the current and distant motivation will lead to the consent of the people and the power, interpersonal trust and in general to progress [29].

At economic independence of regions differentiation of the levels of development hardly will decrease at once. But in a self-assessment of regions it will be perceived as "fair" as it will be result of own activity, in a smaller measure subject to 
destructive external influences. It has to smooth the contradictions connected with inequality.

It is also necessary to note that the concept about selfdevelopment at the peripheral and developed regions is not unambiguous. At evolution of self-development of peripheral regions, unlike developed, there will be a component - need of strengthening of impulses of the self-movement for development.

The self-movement in development for peripheral regions has one more value - the relation to the state investment and technical assistance, careful, free from parasitism. Without the external help peripheral regions are almost not capable to receive inertia of the movement in development [30].

Ultimate goal "Etc. э." there was first, a justification of need of the external help. Namely, supporters "Etc. э." proved need to refuse dogma about firmness of the developed international division of labor. Furtado S. claimed that static understanding and following to the principle of "comparative expenses" D. Ricardo will never bring underdeveloped countries out of a condition of backwardness [19]. Agrarian specialization of underdeveloped countries without industrial development is a way of preservation of a condition of a periferiynost. The group of the international experts compared a condition of economies of the countries of Africa which are to the south of and to the north of the Sahara. The first refuse the external foreign help, and their economy remains in a stagnant state. The second, constantly using the help of the developed countries, got impulses of the selfmovement and followed a way of self-development [31;32]. By analogy it is possible to claim that reference of regions of Russia in subgroup "less developed agrarian" and the corresponding installations in normative documents have a destructive basis. It is possible to give not one example when federal officials, referring to agrarian specialization, extinguish initiatives of business of regions and foreign investors of placement in the republics of the North Caucasus of the industrial enterprises on favorable credit conditions. Destruction is that the agrarian focused regions cannot actively develop, without having a minimum of the industrial enterprises generating a commercial crop in territories. Without commercial crop there can be neither modernization bases of development, nor the same full-blooded agrarian specialization, nor in general economic success. Secondly, in "Etc. э." the concept of dependent development which proves a duty of the developed countries to help underdeveloped countries with peripheral economy is put forward. The solution comes down to a thesis that development of the countries of the Center, concentration of their capital, is reached at the expense of an underdevelopment of the countries of the periphery by centuries-old pumping out of resources. Therefore the countries of the center are nowadays obliged to assist the countries to the periphery in development $[13 ; 15 ; 19]$. But a part of authors critically belong to the foreign help as to the factor which parasitic is decomposing and promoting political and economic dependence of the countries of the periphery on the Center countries $[14 ; 16 ; 17]$.
Refracting told to peripheral regions of the certain country it is possible to tell that, first, peripheral regions have favorable climatic conditions and convenient border geographic location for integration of economy both with regions of the country, and with the abroad which are objective conditions for optimum development of both agrarian, and industrial spheres. There are no reasons for removal of a sentence to them - "less developed agrarian". At such discrimination Russia will remain at the deadlock of a territorial imbalance and the general lag in development. Secondly, meaning not the relation of the countries of the world, but regions of the certain country, the speech has to go not about dependent development, and about interdependent. Thirdly, transition to self-development does not represent sense without observance of the imperatives excluding parasitism and obliging effective use by regions of the centralized resources provided by the state (investments, technologies and so forth).

\section{Conclusion}

In the last quarter of the century Russia developed on a vector of negative modernization orientation. Constantly the territorial asymmetry in the levels of development increased. The most backward regions in development are defined as "less developed agrarian". The analysis of type of problematical character of these regions defines their state not as depressive and as territories with economy of peripheral character with the lines corresponding to postulates of the Theory of peripheral capitalism (Prebish R.) - chronic lag in development, poverty of the population, a periferiynost of consciousness and practical culture, weakness of impulses of the self-movement in development.

All this is a consequence of the infernal condition of the public environment which arose countrywide and aggravated in backward regions. The weakness and inefficiency of all hierarchy of public administration injecting a money-making virus in society is the main reason of a negative condition of the public environment. The last was the main obstacle to disclosure of the potential of constructive labor which is in vain in all spheres of useful activity and formation of regions on the way of modernization development.

The problem of overcoming a periferiynost is not isolated. It is additional loading on overcoming weakness of impulses of the self-movement in development of regions of outsiders in a common problem of modernization of national economy.

Improvement of the public environment assumes creation of conditions of stimulation altruistic and repayments of the egoistical beginnings in qualitative conditions of society. The history of development of the countries demonstrates that the transformations directed to creation of similar conditions are carried out on the basis of their initiation by the state "from above" under the influence of civil activity "from below". But in Russia historically it developed so that all transformations were initiated "from above" - the state. The role of civil activity remained and so far remains insignificant; now in regions it is repaid by a demonizing 
equally of both extremism, and constructive movements. The history also demonstrates that at strong public administration and in the presence of bases for his perception by society as fair, positive qualities of the public environment are stimulated.

Therefore, a key link of social and economic transformations in Russia is regeneration first of all of state bodies on bases of a non-economic side of economy patriotism. The complexity is that now over elite of public administration there is no external control and on this basis responsibility of subjects of management for results of social and economic development of the country is weakened. Now a situation such is that neither in authorities, nor in society there is no sufficient measure of vision of need of radical restructurings for the system of public administration as conditions of self-preservation and protection of society against catastrophic collisions. Such depth and width of understanding with which transformations will be perceived as objective need at all levels of society is necessary. Cannot be that the threat of loss of stability of society and integrity of the country did not withdraw in vanguard patriotic forces which will carry out transformation not only economic institutional installations, but also installations sociological, legal, politological and other institutions.

\section{Notes}

1. Bases of state policy of regional development of the Russian Federation until 2025. Decree of the Russian President of January 16, 2017 No. 13.

About the Strategy of economic security of Russia till 2030. Decree of the Russian President of 13.05.2017 No. 208

The strategy of spatial development of the Russian Federation until 2025. Federal Law No. 172-FZ of June 28, 2014.

2. The preference is Hereinafter given to indicators 2013 as in connection with a new wave of recession in economy of Russia indicators of the next years distort objectivity of characteristic of an essence of a periferiynost.

3. With the sign(s) the frequency rate of excess of size of an average value across Russia over an indicator of the explored region, with the sign () - a share of average size of an indicator across Russia in a region indicator is given.

4. The Deviation is connected with employment of the population service of the subjects to sanatorium appointment which are mainly located in the cities of K-BR.

5. The Deviation is connected with movement of the population caused by a border problem of claim of Ingushetia on the Suburb of North Ossetia.

6. If to consider all regions of subgroup "less developed agrarian", then especially lagging behind it is possible to rank the Republic of Tyva, the Jewish and Transbaikal autonomous areas as number.

7. Wikipedia. Lines of industrial society//Electron. text it is given. - Access mode: https://ru.wikipedia.org/wiki/Индустриальное_общество

\section{References}

[1] Anisimova, G. V. (2016.). Methodological aspects of the analysis of economic inequality: Soviet and Post-Soviet problems//TERRA ECONOMICUS. Release 1 (14): 61-77.

[2] Plotnikov, V., Fedotova, G., Popkova, E., Kastyurina, A. (2015). Harmonization of Strategic Planning Indicators of Territories' Socioeconomic Growth. Regional and Sectoral Economic Studies 15-20: 105-114.

[3] Volkov, S. K. (2015). Social and Economic Disproportion of Development of Russian Territories. Regional and Sectoral Economic Studies 15-20: 137-144.

[4] Kleyner, G. B. (2015). Stability of the Russian economy in a mirror of the system economic theory (Part 1)//Economy Questions 12: 107-123.

[5] Smith, A. (1993). A research about the nature and the reasons of wealth of the people (the book I-III) / the Lane with English, introduction article and E. M. Mayburd's comments. M.: Science: 572.

[6] Glazyev, S. Yu. The global economic crisis as process of replacement of the dominating technological ways / the Full text is published in Economy, crises, risks, safety, selforganization [An electronic resource $]$ http://spkurdyumov.ru/economy/mirovoj-ekonomicheskijkrizis/

[7] Zubarevich, N. V. (2015). The strategy of spatial development after crisis. From big projects to industrial modernization//the Magazine of new economic association 2: 226-230.

[8] Rating of economic and social situation of territorial subjects of the Russian Federation. Results of 2014 are Electronic and text data. - Access mode:

http://vid1.rian.ru/ig/ratings/rating_regions_2015.pdf

[9] Granberg, A. G., Zaytseva, Yu. S. (2003). Gross regional product: interregional comparisons / A. G. Granberg, Yu. S. Zaytseva-M.: SOPS publishing house: 117 .

[10] Tatarkin, A. I. (2016). Regional orientation of economic policy of the Russian Federation as institute of spatial arrangement of territories//Economy of the region 12 (1): 927.

[11] Golyashev, A. V., Grigoriev, A. M. Types of Russian regions: stability and shifts in 2003-2013 years / Report in Analytical center at the Government of the Russian Federation. 2014 [Electronic

http://ac.gov.ru/files/publication/a/4363.pdf resource]

[12] Gladky, Yu. N. (2002). Regionovedeniye / Yu. N. Gladky, A. I. Chistobayev. M.: Gaidar supporters: 384.

[13] Prebish, R. (1992). Peripheral capitalism: whether there is to it an alternative? / Translation of prod.: Capitalismo periferico. Crisis y transformacion/Raul Prebisch (Mexico, Fondo de Cultura Economica, 1981). M.: SILT: 337 pages.

[14] Amin, C. Imperialism and unequal development//Electronic test data. - Access mode: https://ru.wikipedia.org/wiki/Amin_samir

[15] Cardoso, F. H. and Faletto, E. (1978). Dependency and Development in Latin America. Berkeley etc: 1727. 
[16] Dos, Santos T. (1971) The Structure of Dependence // Readings in U. S. Imperualism. Ed. by K. T. Farm and D. S. Hodges. Boston: 226.

[17] Wallerstein, I. (1992). The West Capitalism, and the Modern World-System // Review, XV, 4, Fall: 561-619.

[18] Artobolevsky, S. S. (2008). Western experience of implementation of regional policy: opportunities and restrictions of practical use//Regional researches 2: 3-16.

[19] Furtado, C. (1970). La economica Latinoamerucana. Unasintsic des de la concuista iberica hasta la revokucion cubana. Santiago de Chili. Ed Universituria: 311.

[20] Bogomolov, O. T., Kuzyk, B. N. (2010). Non-economic sides of economy: unknown influence. Scientific and publicistic notes of social scientists - M.: INES publishing house: 796 .

[21] Regions of Russia. Socio-economic indexes.

[22] Lenin, V. I. (1981). Collected works. Prod. 5. T. 41. M.: Publishing house of political literature: 241-254.

[23] Sagidov, Yu. N. (1990). Management of an innovative complex at the level of autonomous republics / Yu. N. Sagidov. The thesis for a degree of the Doctor of Economics. M.: Institute of economy of Academy of Sciences of the USSR: 335 .

[24] Sagidov, Yu. N. (2014). Motivational motives as development factor//Regional economy: theory and practice 46: 13-23.
[25] Samuel, Bowles, Herbert, Gintis (2011). A Cooperative Species: Human Reciprocity and its Evolution Prunceton Universiti Press: 288.

[26] Myurdal, G. (1958). World economy. Problems and prospects / G. Myurdal//M.: State publishing house of foreign literature: 555 .

[27] Prebish, R. (1977). Current problems of social and economic development / R. Prebish//Latin America 6: 44-52.

[28] Bochkov, V. S. (2013). Resilience of the territory: contents and ways of strengthening // Region Economy 3: 26-37.

[29] George, A. Akerlof, Robert, J. Shiller (2011). Animal Spirits: How Human Psychology Drives the Economy, and Why It Matters for Global Capitalism. Princeton University Press: 264.

[30] Huillery, Elise (april 2009). History Matters: The Long-Term Impact of Colonial Public Investments in French West Africa. American Economic Journal: Applied Economics 1 (2): 176215.

[31] Guisan, M. C., Aguayo, E. (2015). Manufacturing and Development in Countries and Areas of America, 2000-2010. Regional and Sectoral Economic Studies 15-1: 187-192.

[32] Gerber, Alan S., Dean, Karlan and Daniel, Bergan (april 2009). Does the Media Matter? A Field Experiment Measuring the Effect of Newspapers on Voting Behavior and Political Opinions. American Economic Journal: Applied Economics 1 (2): 35-52. 